\title{
PRINSIP KEADILAN DALAM PAJAK ATAS UMKM
}

\author{
Wendy Endrianto \\ Accounting and Finance Department, Faculty of Economic and Communication, BINUS University \\ Jln. K.H. Syahdan No. 9, Palmerah, Jakarta Barat 11480 \\ w.endrianto@binus.ac.id
}

\begin{abstract}
The purpose of this study is to provide a clear view and criticize opposing dualism that occurs between the spirit of the government in the pursuit of more dominant country's revenue target (As in the issuance of PP 46 in 2013), compared to provide convenience to Small and Medium Enterprises (SMEs) in calculating, depositing, and reporting of Income Tax payablee in order to encourage SMEs to more easily gain access to the financial sector, capital and bank credit. However, whether the regulations are in accordance with the principles of justice that should be owned by every tax legislation? The method used was a descriptive study of the regulation and related legislation, and is expected to be a positive input to the Government, especially the Directorate General of Taxation (DGT).
\end{abstract}

Keywords: SMEs, tax law, income tax

\begin{abstract}
ABSTRAK
Tujuan penelitian ini adalah memberikan pandangan yang jelas dan mengkritisi dualisme yang bertentangan yang terjadi antara semangat pemerintah dalam mengejar target penerimaan negara yang lebih dominan (Terlihat dalam penerbitan PP 46 Tahun 2013), dibandingkan dengan memberikan kemudahan kepada UMKM dalam melakukan penghitungan, penyetoran, dan pelaporan Pajak Penghasilan yang terutang dalam rangka mendorong UMKM untuk lebih mudah mendapat akses ke sektor keuangan, permodalan dan kredit perbankan. Tetapi apakah peraturan tersebut telah sesuai dengan asas keadilan yang harus dimiliki oleh setiap perundang-undangan pajak? Metode yang digunakan adalah deskriptif dengan studi atas regulasi dan perundang-undangan terkait, dan diharapkan dapat menjadi masukan yang positif bagi Pemerintah khususnya Direktorat Jendral Pajak (DJP).
\end{abstract}

Kata kunci: UMKM, hukum pajak, pajak penghasilan 


\section{PENDAHULUAN}

Indonesia berada di urutan keempat untuk negara berpopulasi terbesar, setelah Cina, India, dan Amerika Serikat dengan populasi penduduk mencapai 237,6 juta orang pada 2010. Pada tahun 2013 Populasi Penduduk meningkat menjadi 250 juta orang atau naik sebesar 6\% dari tahun 2010. Dengan jumlah populasi yang besar, penduduk merupakan salah satu roda penggerak ekonomi yang sangat besar potensinya untuk dapat memajukan negara. Ekonomi kerakyatan kemudian menjadi salah satu issue yang menarik ditengah perkembangan perekonomian global yang sedang digaungkan. Ekonomi kerakyatan dianggap sebagai roda utama penggerak ekonomi negara yang dapat menjangkau keseluruh pelosok negeri. Lepas dari kegiatan per politikan yang sedang marak saat ini, ekonomi kerakyatan adalah solusi ideal dalam membangun dan meningkatan taraf hidup masyarakat Indonesia secara keseluruhan.

Ekonomi mikro, kecil dan menengah adalah tiga kelompok ekonomi yang dapat menyentuh semua lapisan masyarakat di seluruh negeri, dari kota hingga daerah-daerah yang terpencil sekalipun. Persebaran kegiatan ekonomi tersebut membentuk suatu tata ekonomi yang secara struktural sangat berperan dalam kegiatan ekonomi nasional. Hutomo (2000) menyebutkan bahwa tata ekonomi yang dapat memberikan jaminan keadilan bagi rakyat adalah tata ekonomi yang pemilikan aset ekonomi nasional terdistribusi secara baik kepada seluruh rakyat, sehingga sumber penerimaan (income) rakyat tidak hanya dari penerimaan upah tenaga kerja, tetapi juga dari sewa modal dan deviden. Secara ekonomis, dalam perekonomian kerakyatan, model income masyarakat adalah sebagai berikut:

$$
Y_{i}=(W+\pi+i s)_{i} .
$$

$Y_{i}$ adalah income individu anggota masyarakat, $W$ adalah penerimaan dari upah tenaga kerja, $\pi$ adalah penerimaan dari deviden atau bagi hasil sisa usaha, $i$ adalah tingkat sewa modal (misalnya bunga deposito), dan ${ }^{S}$ adalah jumlah tabungan atau endowment yang disewakan. Dengan demikian dalam tata ekonomi kerakyatan, masyarakat bukan hanya sebagai buruh dalam perekonomian tetapi juga pemilik atau memiliki saham di sektor produksi.

Kegiatan usaha yang berbasis Usaha Mikro, Kecil dan Menengah (UMKM) sudah sejak lama mendominasi perekonomian Indonesia dan terus berkembang seiring dengan kemudahan dan fasilitas yang diberikan pemerintah dari sisi informasi maupun bantuan kredit yang disalurkan. Di sisi lain dominasi ini belum dapat menyamai penerimaan pajak yang diperoleh dari UMKM, data menunjukkan bahwa sebagian besar penerimaan pajak didominasi oleh wajib pajak besar yang jumlahnya kurang dari 1\%. Beberapa penyebabnya adalah fakta bahwa Direktorat Jendral Pajak (DJP) lebih fokus pada wajib pajak besar sedangkan pengawasan kepada pelaku UMKM belum secara optimal dilakukan dan kepatuhan pajak pelaku UMKM juga masih rendah. Kepatuhan pajak terkait dengan prosedur, tata cara perhitungan dan lainnya yang masih cukup sulit untuk diterapkan dan sedikit membingungkan bagi pelaku UMKM.

Hasan Basri (2014) menjelaskan bahwa Laporan Keuangan Pemerintah Pusat (LKPP) 20042013 menyebutkan realisasi penerimaan pajak selama 2004-2013 hanya Rp4.989 triliun atau 95\% dari target Rp5.241 triliun sepanjang 10 tahun. Menurut Dirjen Pajak Fuad Rahmani, penerimaan perpajakan dari sektor usaha kelas menengah ini akan terus ditingkatkan karena potensinya yang cukup tinggi. Sementara untuk kinerja pendapatan negara dari usaha kecil tidak terlalu baik. Penyebab dari rencana penerimaan yang tidak tercapai adalah pelemahan ekonomi yang berimbas pada penurunan kinerja terutama sektor pertambangan. Faktanya memang dampak krisis global sampai dengan saat ini belum hilang, terutama bagi negara-negara maju yang selama ini merupakan pasar terbesar bagi produk tambang Indonesia. 
Akibat melemah nya perekonomian akibat krisis ekonomi glogal, sektor Usaha Mikro Kecil dan Menengah (UMKM), telah terbukti ketangguhannya dan telah menyelamatkan perekonomian Indonesia pada saat-saat krisis ekonomi berlangsung. Pada saat negara-negara maju mengalami krisis yang melemahkan ekonomi, Indonesia mencatatkan angka positif dalam pertumbuhan ekonomi. Hal ini karena kontribusi dari sektor UMKM.

Menurut data Badan Pusat Statistik (BPS) tahun 1998, dalam periode 4 tahun mulai tahun 1994, secara rerata, lebih dari 99\% jumlah pengusaha yang ada adalah pengusaha pelaku UMKM (industri sekala kecil). Mereka menyediakan 66\% lapangan pekerjaan dengan nilai produksi mencakup lebih dari $88 \%$ dari total nilai produksi yang dihasilkan dan meliputi hampir semua sektor usaha: sektor pertanian (57,9\%), sektor industri pengolahan (6,9\%), sektor perdagangan, rumah makan dan hotel (24\%) dan sisanya bergerak dibidang lain.

Bagaimana halnya dari sisi perpajakan? UMKM ternyata belum dapat memberikan kontribusi yang signifikan terhadap penerimaan pajak. UMKM mendominasi struktur usaha yang ada di Indonesia sekitar 99,99\%, yang terdiri dari usaha mikro 98,79\%, usaha kecil sebesar 1,11\%, usaha menengah sebesar $0,09 \%$. Sedangkan Usaha besar hanya berkontribusi dalam struktur usaha di Indonesia sebesar $0,01 \%$. Potensi penerimaan pajak dari usaha kecil menengah (UKM) pada lima tahun mendatang diperkirakan bisa mencapai Rp400 triliun. Namun, butuh dukungan para pelaku UKM di Indonesia demi memenuhi kewajiban membayar pajak sebesar 1\% dari omzet usahanya.

Terkait dengan UMKM, sebelumnya sudah ada ketentuan perpajakan yang mengatur tarif khusus PPh untuk UMKM tetapi hanya berlaku untuk yang berbentuk badan usaha. Dalam Undangundang No.36 Tahun 2008 (UU PPh) pasal 31 E dinyatakan bahwa Wajib Pajak badan dalam negeri dengan peredaran bruto sampai dengan Rp50 miliar mendapat fasilitas berupa pengurangan tarif sebesar 50\%. Dengan tarif PPh Badan yang berlaku saat ini yaitu 25\%, maka bagi Wajib Pajak badan dalam negeri yang memenuhi syarat, tarif efektifnya menjadi $12,5 \%$ atas penghasilan sampai dengan Rp.4,8 miliar. Pengenaan PPh dalam hal ini dilakukan terhadap penghasilan kena pajak yang dihitung dari perhitungan laba-rugi akuntansi (pembukuan) setelah dilakukan koreksi fiskal, karena berdasarkan pasal 28 ayat (1) Undang-undang Nomor 28 Tahun 2007 (UU KUP), Wajib Pajak badan diwajibkan menyelenggarakan pembukuan.

Wacana untuk mengenakan pajak khusus untuk UMKM sudah dimulai sejak tahun 2011. Baru terealisasi pada Juni 2013. Pada awalnya, ide pajak atas UMKM aneh. Sebagian menolak karena bertentangan dengan UU PPh yang mengatur bahwa Pajak Penghasilan dikenakan atas penghasilan neto dengan tarif progresif. Semakin tinggi penghasilan semakin tinggi tarif. Bagaimana pemerintah menyiasati wacana pajak khusus UMKM?

Aturan pajak UMKM harus semudah mungkin bisa diterapkan untuk semua kriteria UMKM, sebab selama ini UMKM dengan omzet kecil tidak memiliki pembukuan yang jelas sebagai dasar mereka melakukan kewajiban dalam pembayaran pajak pada negara. Ditinjau dari konsep keadilan dalam pemajakan (equity principle), pengenaan PPh Final tidak sesuai dengan keadilan karena tidak mencerminkan kemampuan membayar (ability to pay). Pemajakan yang adil adalah bahwa semakin besar penghasilan maka semakin besar pula pajak yang harus dibayar. Ini disebut dengan keadilan vertikal atau vertical equity. 


\section{METODE}

Penelitian dilakukan dengan melakukan studi atas regulasi dan perundang-undangan yang ada serta memberikan pandangan yang jelas atas keberadaan peraturan tersebut guna memberi masukan yang penting dari segi hukum yang berlaku. Data didapatkan dari studi kepustakaan atas literatur perundang-undangan yang berkaitan dengan judul, selain itu juga dilakukan penggalian lebih dalam dengan melihat tren atas dampak pemberlakuan peraturan tersebut pada pelaku bisnis. Dari data regulasi dan penerapannya kemudian dilakukan analisa apakah ada kesesuaian kemudian menarik kesimpulan dari penelitian apakah mempunyai pengaruh yang positif atau negatif bagi sektor bisnis yang terlibat.

\section{HASIL DAN PEMBAHASAN}

\section{Definisi}

\section{Undang-Undang Nomor 20 Tahun 2008}

Undang-Undang Nomor 20 Tahun 2008 tentang Usaha Mikro, Kecil dan Menengah (UMKM): Usaha Mikro adalah usaha produktif milik orang perorangan dan/atau badan usaha perorangan yang memenuhi kriteria Usaha Mikro sebagaimana diatur dalam Undang-Undang ini. Usaha Mikro memiliki kriteria asset maksimal sebesar 50 juta dan omzet sebesar 300 juta. Usaha Kecil adalah usaha ekonomi produktif yang berdiri sendiri, yang dilakukan oleh orang perorangan atau badan usaha yang bukan merupakan anak perusahaan atau bukan cabang perusahaan yang dimiliki, dikuasai, atau menjadi bagian baik langsung maupun tidak langsung dari usaha menengah atau usaha besar yang memenuhi kriteria Usaha Kecil sebagaimana dimaksud dalam Undang-Undang ini.

Usaha Kecil memiliki kriteria asset sebesar 50 juta sampai dengan 500 juta dan omzet sebesar 300 juta sampai dengan 2,5 miliar. Usaha Menengah adalah usaha ekonomi produktif yang berdiri sendiri, yang dilakukan oleh orang perseorangan atau badan usaha yang bukan merupakan anak perusahaan atau cabang perusahaan yang dimiliki, dikuasai, atau menjadi bagian baik langsung maupun tidak langsung dengan Usaha Kecil atau usaha besar dengan jumlah kekayaan bersih atau hasil penjualan tahunan sebagaimana diatur dalam Undang-Undang ini. Usaha Menengah memiliki kriteria asset sebesar 500 juta sampai dengan 10 miliar dan omzet sebesar 2,5 miliar sampai dengan 50 miliar.

\section{Keputusan Menteri Keuangan Nomor 316/KMK 016/1994}

Menurut Kementrian Keuangan. Berdasarkan Keputusan Menteri Keuangan Nomor 316/KMK 016/1994 tanggal 27 Juni 1994 bahwa Usaha Kecil sebagai perorangan/badan usaha yang telah melakukan kegiatan /usaha yang mempunyai penjualan/omset per tahun setinggi-tingginya Rp. 600.000.000 atau asset (aktiva ) setinggi-tingginya Rp.600.000.000 (diluar tanah dan bangunan yang ditempati ). Contohnya, Firma, CV, PT, dan Koperasi yakni dalam bentuk badan usaha. Sedangkan contoh dalam bentuk perorangan antara lain pengrajin industri rumah tangga, peternak, nelayan, pedagang barang dan jasa dan yang lainnya.

\section{Undang-Undang Nomor 9 tahun 1995}

Undang-Undang Nomor 9 tahun 1995 tentang mengatur kriteria usaha kecil berdasarkan nilai aset tetap (di luar tanah dan bangunan) paling besar Rp 200 juta dengan omzet per tahun maksimal Rp 
1 milyar. Sementara itu berdasarkan Inpres No.10 tahun 1999 tentang usaha menengah, batasan aset tetap (di luar tanah dan bangunan) untuk usaha menengah adalah Rp 200 juta hingga Rp 10 milyar.

\section{Kementerian Koperasi dan UKM}

Kementerian Koperasi dan UKM menggolongkan suatu usaha sebagai usaha kecil jika memiliki omset kurang dari Rp 1 milyar per tahun. Untuk usaha menengah batasannya adalah usaha yang memiliki omset antara Rp 1 sampai dengan Rp 50 milyar per tahun.

\section{Departemen Perindustrian dan Perdagangan}

Departemen Perindustrian dan Perdagangan menetapkan bahwa industri kecil dan menengah adalah industri yang memiliki nilai investasi sampai dengan Rp 5 milyar. Sementara itu usaha kecil di bidang perdagangan dan industri juga dikategorikan sebagai usaha yang memiliki aset tetap kurang dari Rp 200 juta dan omzet per tahun kurang dari Rp 1 milyar (sesuai UU no.9 tahun 1995)

\section{Bank Indonesia}

Bank Indonesia menggolongkan usaha kecil dengan merujuk pada UU no 9/1995, sedangkan untuk usaha menengah BI menentukan sendiri kriteria aset tetapnya dengan besaran yang dibedakan antara industri manufaktur (Rp 200 juta s/d Rp 5 miliar) dan non manufaktur (Rp 200 - 60 juta).

\section{Badan Pusat Statistik (BPS)}

Badan Pusat Statistik (BPS) memberikan definisi UMKM berdasarkan kuantitas tenaga kerja. Usaha kecil merupakan usaha yang memiliki jumlah tenaga kerja 5 orang sampai dengan 19 orang, sedangkan usaha menengah merupakan usaha yang memiliki jumlah tenaga kerja 20 orang sampai dengan 99 orang.

Keberagaman definisi yang ditetapkan oleh masing-masing instansi menjelaskan sudut pandang dan kegunaan yang berbeda. Mereka mempunyai tujuan dan kepentingan yang berbeda dalam menjalankan fungsi pengawasan dan pengendalian sesuai dengan instansinya masing-masing. Yang menjadi menarik adalah apakah masing-masing instansi tersebut tidak akan saling berselisih faham ketika data-data mereka disajikan dalam suatu kesempatan yang sama?

\section{UMKM dan Perpajakan}

Rencana menjadikan UMKM sebagai fokus pemajakan telah terdengar sejak tahun 2011. Saat itu sumber data menunjukan bahwa UMKM menyumbang 58\% dari PDB tetapi kontribusi nya terhadap total penerimaan pajak hanya $5 \%$. 
Tabel 1 Perkembangan Data Usaha Mikro, Kecil, Menengah (UMKM) dan Usaha Besar (UB) Tahun 2011-2012

\begin{tabular}{|c|c|c|c|c|c|c|c|c|}
\hline \multirow{2}{*}{ No } & \multirow{2}{*}{ INDIKATOR } & \multirow{2}{*}{ SATUAN } & \multicolumn{2}{|c|}{ TAHUN 2011} & \multicolumn{2}{|c|}{ TAHUN 2012} & \multicolumn{2}{|c|}{ PERKEMBANGAN TAHUN 2011- } \\
\hline & & & JUMLAH & PANGSA (\%) & JUMLAH & PANGSA (\%) & JUMLAH & $(\%)$ \\
\hline (1) & (2) & (3) & (4) & (5) & (6) & (7) & (8) & (9) \\
\hline \multirow[t]{6}{*}{1} & UNIT USAHA (A+B) & (Unit) & 55.211 .396 & & 56.539 .560 & & 1.328 .163 & 2,41 \\
\hline & A. Usaha Mikro, Kecil dan Menengah (UMKM) & (Unit) & 55.206 .444 & 99,99 & 56.534 .592 & 99,99 & 1.328.147 & 2,41 \\
\hline & - Usaha Mikro (UMi) & (Unit) & 54.559 .969 & 98,82 & 55.856 .176 & 98,79 & 1.296.207 & 2,38 \\
\hline & - Usaha Kecil (UK) & (Unit) & 602.195 & 1,09 & 629.418 & 1,11 & 27.223 & 4,52 \\
\hline & - Usaha Menengah(UM) & (Unit) & 44.280 & 0,08 & 48.997 & 0,09 & 4.717 & 10,65 \\
\hline & B. Usaha Besar (UB) & (Unit) & 4.952 & 0,01 & 4.968 & 0,01 & 16 & 0,32 \\
\hline \multirow[t]{7}{*}{2} & TENAGA KERJA (A+B) & (Orang) & 104.613 .681 & & 110.808 .154 & & 6.194 .473 & 5,92 \\
\hline & A. Usaha Mikro, Kecil dan Menengah (UMKM) & (Orang) & 101.722 .458 & 97,24 & 107.657.509 & 97,16 & 5.935 .051 & 5,83 \\
\hline & - Usaha Mikro (UMi) & (Orang) & 94.957 .797 & 90,77 & 99.859 .517 & 90,12 & 4.901 .720 & 5,16 \\
\hline & - Usaha Kecil (UK) & (Orang) & 3.919 .992 & 3,75 & 4.535 .970 & 4,09 & 615.977 & 15,71 \\
\hline & - Usaha Menengah(UM) & (Orang) & 2.844 .669 & 2,72 & 3.262 .023 & 2,94 & 417.354 & 14,67 \\
\hline & B. Usaha Besar (UB) & (Orang) & 2.891 .224 & 2,76 & 3.150 .645 & 2,84 & 259.422 & 8,97 \\
\hline & & & & 6,26 & & & & \\
\hline \multirow[t]{7}{*}{3} & PDB ATAS DASAR HARGA BERLAKU (A+B) & (Rp Milyar) & 7.445 .345 & & 8.241 .864 & & 796.520 & 10,70 \\
\hline & A. Usaha Mikro, Kecil dan Menengah (UMKM) & (Rp. Milyar) & 4.321 .830 & 58,05 & 4.869 .568 & 59,08 & 547.738 & 12,67 \\
\hline & - Usaha Mikro (UMi) & (Rp. Milyar) & 2.579 .388 & 34,64 & 2.951 .121 & 35,81 & 371.732 & 14,41 \\
\hline & - Usaha Kecil (UK) & (Rp. Milyar) & 740.271 & 9,94 & 798.122 & 9,68 & 57.851 & 7,81 \\
\hline & - Usaha Menengah(UM) & (Rp. Milyar) & 1.002 .170 & 13,46 & 1.120 .325 & 13,59 & 118.155 & 11,79 \\
\hline & B. Usaha Besar (UB) & (Rp. Milyar) & 3.123 .515 & 41,95 & 3.372 .296 & 40,92 & 248.782 & 7,96 \\
\hline & & & & 23,70 & & & & \\
\hline \multirow[t]{6}{*}{4} & PDB ATAS DASAR HARGA KONSTAN 2000 (A- & (Rp Milyar) & 2.377 .110 & & 2.525 .120 & & 148.010 & 6,23 \\
\hline & A. Usaha Mikro, Kecil dan Menengah (UMKM) & (Rp. Milyar) & 1.369 .326 & 57,60 & 1.451 .460 & 57,48 & 82.134 & 6,00 \\
\hline & - Usaha Mikro (UMi) & (Rp. Milyar) & 761.229 & 32,02 & 790.826 & 31,32 & 29.597 & 3,89 \\
\hline & - Usaha Kecil (UK) & (Rp. Milyar) & 261.316 & 10,99 & 294.261 & 11,65 & 32.945 & 12,61 \\
\hline & - Usaha Menengah(UM) & (Rp. Milyar) & 346.781 & 14,59 & 366.374 & 14,51 & 19.593 & 5,65 \\
\hline & B. Usaha Besar (UB) & (Rp. Milyar) & 1.007 .784 & 42,40 & 1.073 .660 & 42,52 & 65.876 & 6,54 \\
\hline
\end{tabular}

Sumber: www.depkop.go.id

Melihat besarnya potensi penerimaan pajak dari UMKM yang belum tergali secara maksimal, maka sejak tahun 2012 pemerintah mulai mempersiapkan sebuah peraturan pemerintah yang mengatur perusahaan atau dalam hal ini adalah wajib pajak dengan penghasilan atau peredaran bruto tertentu. Peraturan Pemerintah No 46 tahun 2013 (PP 46 tahun 2013) tentang Pajak Penghasilan atas penghasilan dari usaha yang diterima atau diperoleh wajib pajak yang memiliki peredaran bruto tertentu disahkan pada tanggal 12 Juni 2013 oleh Presiden adalah jawaban atas inisiasi pemerintah dalam menjaring wajib pajak dari UMKM.

Pertimbangan pemerintah atas terbitnya PP 46 tahun 2013 adalah kesederhanaan dalam pemungutan pajak, berkurangnya beban administrasi baik bagi wajib pajak maupun Dirjen Jenderal Pajak, serta memperhatikan perkembangan ekonomi dan moneter. Hal yang menjadi tujuan utama dalam ditetapkannya peraturan tersebut adalah meningkatkan penerimaan pajak dari sektor UMKM, maka pendekatan yang ada juga harus menyesuaikan dengan perilaku dan prinsip kesederhanaan yang berlaku pada sektor tersebut. Kemudahan atau kesederhanaan dalam penghitungan, penyetoran dan pelaporan pajak terutang adalah solusi yang kemudian ditawarkan dalam peraturan ini.

PP No 46 tahun 2013 ini menetapkan objek pajak adalah penghasilan dari usaha yang diterima atau diperoleh Wajib Pajak yang memiliki peredaran bruto tidak melebihi Rp4.800.000.000,00 atau empat miliar delapan ratus juta rupiah dalam satu tahun pajak. Sedangkan subjek pajak adalah wajib pajak orang pribadi atau wajib pajak badan tidak termasuk bentuk usaha tetap. Ada beberapa pengecualian atas subjek pajak adalah sebagai berikut: (1) Wajib Pajak Orang pribadi yang bukan kriteria Peraturan Pemerintah ini adalah: Wajib Pajak Orang Pribadi yang menggunakan sarana atau prasarana yang dapat dibongkar pasang, baik yang menetap maupun tidak menetap dan Wajib Pajak Orang Pribadi yang menggunakan sebagian atau seluruh tempat untuk kepentingan umum yang tidak diperuntukkan bagi tempat usaha atau berjualan. (2) Wajib Pajak Badan yang bukan kriteria Peraturan Pemerintah ini adalah: Wajib Pajak badan yang belum beroperasi secara komersial atau Wajib Pajak 
badan yang dalam jangka waktu satu tahun setelah beroperasi secara komersial memperoleh peredaran bruto melebihi Rp4.800.000.000,00 (empat miliar delapan ratus juta rupiah).

Besarnya pajak yang ditetapkan dalam PP No 46 tahun 2013 ini adalah tarif final sebesar 1\%. Pengenaan PPh yang bersifat final bermakna bahwa setelah pelunasan PPh $1 \%$ yang dihitung dari peredaran bruto setiap bulan, kewajiban pajak atas penghasilan tersebut telah dianggap selesai dan final. Tarif tersebut beralaku untuk batas penghasilan usaha seperti dijelaskan pada paragraph sebelumnya, dan bila objek pajak telah melebihi Rp4.800.000.000,00 tidak dikenai Pajak Penghasilan yang bersifat final berdasarkan Peraturan Pemerintah ini tetapi mengikuti ketentuan peraturan perundang-undangan perpajakan yang mengatur mengenai pengenaan pajak atas penghasilan tersebut.

Untuk dapat menjelaskan pengelompokan dari penghasilan bruto, dalam peraturan pemerintah ini mengelompokkan penghasilan menjadi: (1) Penghasilan dari pekerjaan dalam hubungan kerja dan pekerjaan bebas seperti gaji, honorarium, penghasilan dari praktek dokter, notaris, aktuaris, akuntan, pengacara, dan sebagainya. (2) Penghasilan dari usaha dan kegiatan. (3) Penghasilan dari modal, yang berupa harta gerak ataupun harta tak gerak, seperti bunga, dividen, royalti, sewa, dan keuntungan penjualan harta atau hak yang tidak dipergunakan untuk usaha. (4) Penghasilan lain-lain, seperti pembebasan utang dan hadiah.

Untuk penghasilan jasa sehubungan dengan pekerjaan bebas meliputi: (1) Tenaga ahli yang melakukan pekerjaan bebas, yang terdiri dari pengacara, akuntan, arsitek, dokter, konsultan, notaris, penilai, dan aktuaris. (2) Pemain musik, pembawa acara, penyanyi, pelawak, bintang film, bintang sinetron, bintang iklan, sutradara, kru film, foto model, peragawan/peragawati, pemain drama, dan penari. (3) Olahragawan. (4) Penasihat, pengajar, pelatih, penceramah, penyuluh, dan moderator. (5) Pengarang, peneliti, dan penerjemah. (6) Agen iklan. (7) Pengawas atau pengelola proyek. (8) Perantara. (9) Petugas penjaja barang dagangan. (10) Agen asuransi. (11) Distributor perusahaan pemasaran berjenjang (multilevel marketing) atau penjualan langsung (direct selling) dan kegiatan sejenis lainnya.

Apabila Wajib Pajak mempunyai penghasilan dari luar negeri dan terutang, maka Wajib Pajak dapat mengkreditkan terhadap pajak penghasilan yang terutang. Apabila perusahaan menderita kerugian maka dapat melakukan kompensasi kerugian dengan penghasilan yang tidak dikenakan PPh Final dengan ketentuan sebagai berikut: (1) Kompensasi kerugian dilakukan mulai Tahun Pajak berikutnya berturut-turut sampai dengan lima Tahun Pajak. (2) Tahun Pajak dikenakannya Pajak Penghasilan yang bersifat final ini tetap diperhitungkan sebagai bagian dari jangka waktu lima tahun. (3) Kerugian pada suatu Tahun Pajak dikenakannya Pajak Penghasilan yang bersifat final berdasarkan Peraturan Pemerintah ini tidak dapat dikompensasikan pada Tahun Pajak berikutnya.

\section{Konsep Keadilan Pengenaan PPh UMKM}

Mardiasmo (2009) menyebutkan agar pemungutan pajak tidak menimbulkan hambatan atau perlawanan, maka pemungutan pajak harus memenuhi syarat sebagai berikut: (1) Pemungutan pajak harus adil (Syarat Keadilan). (2) Pemungutan pajak harus berdasarkan undang-undang (Syarat Yuridis). (3) Tidak mengganggu perekonomian (Syarat Ekonomis). (4) Pemungutan pajak harus efisien (Syarat Finansial). (5) Sistem pemungutan pajak harus sederhana.

Syarat keadilan sesuai dengan tujuan hukum, yakni mencapai keadilan, undang-undang pelaksanaan pemungutan harus adil. Adil dalam perundang-undangan adalah mengenakan pajak secara umum dan merata, serta disesuaikan dengan kemampuan masing-masing. Sedang adil dalam pelaksanaan adalah memberikan hak bagi Wajib Pajak untuk mengajukan keberatan, penundaan dalam pembayaran dan mengajukan banding kepada Majelis Pertimbangan Pajak. Asas keadilan ini harus senantiasa dipegang teguh, baik dalam prinsip mengenai perundang-undangannya maupun dalam 
prakteknya sehari-hari. Inilah sendi pokok yang seharusnya diperhatikan baik-baik oleh setiap negara untuk melancarkan usahanya mengenai pemungutan pajak. Maka dari itu, syarat mutlak bagi pembuat undang-undang pajak, juga syarat mutlak bagi aparatur setiap pemerintah yang berkewajiban melaksanakannya, adalah pertimbangan-pertimbangan dan perbuatan-perbuatan yang adil pula.

Brotodihardjo (2003) menguraikan asas pemungutan pajak The Four Maxims yang bersumber dari buku An Inqury into the Nature and Causes of the Wealth of Nations karya Adam Smith (17231790) sebagi berikut: (1) Pembagian tekanan pajak di antara subjek pajak masing-masing hendaknya dilakukan seimbang dengan kemampuannya, yaitu seimbang dengan penghasilan yang dinikmatinya masing-masing, di bawah perlindungan pemerintah (asas pembagian/asas kepentingan). Dalam asas equality ini tidak diperbolehkan suatu negara mengadakan diskriminasi di antara sesama wajib pajak, dalam keadaan yang sama, para wajib pajak harus dikenakan pajak yang sama pula. (2) Pajak yang harus dibayar oleh seseorang harus terang (certain) dan tidak mengenal kompromis (not arbitrary). Dalam asas certainty ini, kepastian hukum yang diutamakan adalah mengenai subjek-objek, besarnya pajak, dan juga ketentuan mengenai waktu pembayarannya. (3) "Every tax ought to be levied at the time, or in the manner, in which it is most likely to be convenient for the contributor to pay I". Teknik pemungutan pajak yang dianjurkan ini (yang disebut juga convenient of payment) menetapkan bahwa pajak hendaknya dipungut pada saat yang paling baik bagi para wajib pajak, yaitu saat sedekatdekatnya dengan detik diterimanya penghasilan yang bersangkutan. (4) "Every tax ought to be so contrived as both to take out and to keep out of the pockets of the people as little as possible over and above what it brings into to public treasury of the State". Asas efisiensi ini menetapkan bahwa pemungutan pajak hendaknya dilakukan sehemat-hematnya; jangan sekali-kali biaya pemungutan melebihi pemasukan pajaknya.

Prinsip keadilan yang dimaksud dalam pemungutan pajak di atas terutama jika dikaitkan dengan pemungutan Pajak Penghasilan ( $\mathrm{PPh}$ ), menurut jenisnya dapat dibedakan lagi menjadi dua macam yaitu prinsip keadilan horizontal dan prinsip keadilan vertikal. Menurut Parwito (2006):

“... Keadilan horizontal dalam perspektif pajak mengandung makna, untuk wajib pajak dengan kondisi kemampuan atau penghasilan yang sama harus dikenakan jumlah pajak yang sama. Sementara keadilan vertikal diartikan semakin tinggi kemampuan ekonomis wajib pajak, semakin tinggi pula beban pajak yang dikenakan. Konsep ini yang mendasari pengenaan pajak penghasilan secara progresif, seperti dianut rezim perpajakan Indonesia...”.

PP 46 tahun 2013 yang mulai diberlakukan pertengan tahun 2014 mempunyai beberapa kelemahan dalam segi regulasi dan tidak sesuai dengan prinsip keadilan. Mansury R (1996) meninjau dari konsep keadilan dalam pemajakan (equity principle), pengenaan tarif final tidak sesuai dengan keadilan karena tidak mencerminkan kemampuan membayar (ability to pay). Pemajakan yang adil adalah bahwa semakin besar penghasilan maka semakin besar pula pajak yang harus dibayar atau disebut dengan keadilan vertikal atau vertical equity. Penghasilan yang dimaksud di sini adalah penghasilan neto, yaitu setelah dikurangi dengan biaya-biaya pengurang penghasilan bruto yang diperkenankan menurut ketentuan perpajakan yang berlaku.

Peraturan tersebut menyebutkan dengan jelas bahwa objek pajak adalah peredaran bruto, sehingga besar kecilnya penghasilan neto seseorang atau badan usaha tidak akan mempengaruhi besarnya pajak yang akan dibayar karena pajak dihitung dengan mengalikan tarif langsung terhadap peredaran bruto. Pendekatan tersebut mengasumsikan bahwa setiap usaha yang dilakukan oleh pengusaha adalah menguntungkan. Pada kenyataanya banyak usaha kecil yang melakukan penjualan hanya untuk memutar persediannya saja tanpa keuntungan sama sekali, hal ini terpaksa dilakukan pengusaha agar kerugian yang diderita tidak berlarut-larut. Keadaan ekonomi pasar yang tidak menentu juga mempengaruhi daya jual dan daya beli konsumen, dengan tarif final terhadap penghasilan neto tersebut dirasa sangat memberatkan pengusaha terutama pada usaha mikro dan kecil. Risiko kerugian masih terlalu besar dan akan langsung mempengaruhi kelangsungan usaha. 
Apabila UMKM dalam bentuk badan usaha mampu meraih persentase penghasilan kena pajak di atas $8 \%$, maka UMKM dalam bentuk badan usaha akan diuntungkan karena membayar PPh lebih kecil dari ketentuan sebelumnya. Demikian sebaliknya akan membayar PPh lebih besar apabila persentase penghasilan kena pajak kurang dari 8\% terhadap peredaran bruto, bahkan akan tetap membayar PPh Final meskipun dalam keadaan merugi. Persentase minimum atas penghasilan kena pajak yang harus dicapai oleh UMKM perorangan akan lebih besar dari 8\% agar tidak dirugikan dengan berlakunya pengenaan tarif final 1\% dari peredaran bruto, sebab dengan berlakunya PP 46 Tahun 2013 Penghasilan Tidak Kena Pajak (PTKP) tidak lagi menjadi faktor pengurang dalam menghitung kewajiban PPh UMKM orang pribadi. Sederhana Tetapi Mundur dari Sistim SelfAssessment.

Namun bagi UMKM perorangan atau badan usaha yang selama ini telah menyelenggarakan pembukuan dengan tertib dan menghitung PPh dari penghasilan kena pajak yang senyatanya dari hasil pembukuan setelah dilakukan koreksi fiskal, ketentuan ini menjadi suatu kemunduran bagi mereka. Betapa tidak, untuk kelompok ini, konsep self-assessment yang memberi kepercayaan kepada Wajib Pajak untuk menghitung, memperhitungkan, menyetor dan melaporkan sendiri kewajiban pajaknya jelas menjadi tidak bermakna. Kebijakan pengenaan PPh Final terhadap UMKM mundur dan tidak selaras dengan tujuan utama dari sistim self-assesment yaitu kepatuhan membayar pajak secara sukarela.

Perlu dipahami bahwa kepatuhan pajak dari para pelaku UMKM masih terlalu rendah, beberapa yang dapat menjadi penyebabnya adalah pertama, pelaku UMKM didominasi oleh pelaku usaha rumah tangga. Berdasarkan pengamatan, kebanyakan pelaku UMKM dari kelompok ini kurang atau tidak peduli dengan masalah ketentuan yang berlaku. Termasuk di dalamnya ketentuan perpajakan. Ketidakpedulian timbul, salah satunya, karena ketidakpahaman atas ketentuan-ketentuan yang berlaku. Pelaksanaan kewajiban perpajakan, seperti mendaftarkan diri untuk memperoleh NPWP. Kewajiban perpajakan lebih banyak karena kebutuhan lain, seperti pengurusan perijinan dan urusan perbankan bukan karena kesadaran bahwa mereka harus berNPWP.

Kedua, Pelaku UMKM umumnya orang pribadi swa-usaha (self employment). Jenis pelaku usaha ini mempunyai karakteristik cenderung kurang patuh dibandingkan dengan karyawan yang penghasilan yang diperolehnya telah dipotong pajak pada saat dibayarkan (witholding). Orang pribadi swa-usaha akan melaporkan seluruh penghasilan dari kegiatan usahanya dalam SPT. Namun, masih awamnya pelaku UMKM mengenai perpajakan menjadikan mereka termasuk dalam kelompok tidak patuh. Selain itu, tidak adanya data lain yang ada di kantor pajak sebagai penguji penghasilan yang dilaporkan akan memberikan insentif pada wajib pajak swa-usaha untuk melaporkan penghasilan secara tidak benar. (3) Pelaku UMKM biasa bergerak di sektor informal, sehingga catatan yang ada atas pelaku UMKM dan transaksi yang dilakukannya relatif tidak ada. Hal ini menimbulkan kesulitan bagi administrasi pajak untuk mengawasi kepatuhan pajak pelaku UMKM. Karena bergerak di sektor informal, ini juga menyebabkan minimnya kesadaran pelaku UMKM untuk berkontribusi pada penyediaan barang dan jasa publik yang berdampak pada rendahnya kepatuhan pajak.

Ketiga, batasan-batasan tersebut sudah seharusnya menjadi pemahaman pemerintah dalam mengeluarkan peraturan perpajakan tersebut. Bahwa menjadikan UMKM menjadi lebih patuh terhadap pajak tidak mudah seperti semangat pemerintah dalam mengejar target penerimaan negara dalam penerbitan PP 46 Tahun 2013 ini. Lebih dari sekedar memberi kemudahan kepada UMKM dalam melakukan penghitungan, penyetoran, dan pelaporan Pajak Penghasilan yang terutang, tetapi dalam rangka mendorong UMKM untuk lebih mudah mendapat akses ke sektor keuangan, permodalan dan kredit perbankan. 


\section{SIMPULAN}

Pihak yang mengundangkan suatu peratuan perundang-undangan harus menerapkan asas kecermatan dan kehati-hatian dalam melakukan penyusunan peraturan perundang-undangan sehingga produk peratuan perundang-undangan tersebut terjamin konstitusionalitas dan kesahihannya sebagai salah satu produk hukum. Pengenaan $\mathrm{PPh}$ dengan tarif $1 \%$ dari peredaran usaha setiap bulan dan bersifat final terhadap UMKM sebagaimana tercantum dalam penjelasan umum PP 46 Tahun 2013 adalah kesederhanaan dalam pemungutan pajak, berkurangnya beban administrasi baik bagi Wajib Pajak maupun Direktorat Jenderal Pajak, serta memperhatikan perkembangan ekonomi dan moneter. Perhitungan pajak ini sangat memudahkan pengusaha UMKM dalam melaksanakan kewajiban perpajakan karena pengusaha UMKM sebagian besar masih melakukan pembukuan tradisional terhadap transaksi usaha mereka. Pengenaan $\mathrm{PPh} 1 \%$ ini juga dapat mendidik pengusaha UMKM untuk patuh dalam kewajiban perpajakan dan memberi kemudahan kepada UMKM dalam melakukan penghitungan, penyetoran, dan pelaporan Pajak Penghasilan yang terutang.

\section{DAFTAR PUSTAKA}

Basri, H. (2014). Pendapatan Pajak UKM 2013 Capai Rp328.94 trilliun. Diakses 1 Agustus 2014 dari http://nasional.kontan.co.id,

Brotodihardjo, R. S. (2003). Pengantar Ilmu Hukum Pajak. Bandung: Refika Aditama.

Hutomo, M. Y. (2000). Konsep Ekonomi Kerakyatan. Seminar Sehari Bappenas. Jakarta

Keputusan Menteri Keuangan. (1994). Nomor 316/KMK 016/1994 tanggal 27 Juni 1994 tentang edoman Pembinaan Usaha Kecil dan Koperasi melalui pemanfaatan dana dari bagian Laba Badan Usaha Milik Negara. Kementerian Keuangan.

Kemeterian Koperasi dan Usaha Kecil dan Menengah. (2012). Data UMKM 2012. Diakses dari http://www.depkop.go.id/index.php?option=com_phocadownload\&view=category\&id=109:da ta-umkm-2012\&Itemid=93

Mansury, R. (1996). Pajak Penghasilan Lanjutan. Jakarta: Indonesia Hill-Co.

Mardiasmo. (2009). Perpajakan, Edisi Revisi 2009. Bulaksumur: Penerbit Andi.

Parwito. (2006). UU Pajak Penghasilan Penuh Distorsi. Harian Bisnis Indonesia.

Republik Indonesia. (2013). Peraturan Pemerintah Nomor 46 tahun 2013 tentang Pajak Penghasilan atas penghasilan dari usaha yang diterima atau diperoleh wajib pajak yang memiliki peredaran bruto tertentu. Lembaran Negara RI Tahun 2013 Nomor 106. Kementerian Hukum dan HAM. Jakarta.

. (2008). Undang-Undang No. 36 Tahun 2008 tentang Perubahan Keempat atas UndangUndang nomor 7 tahun 1983 Tentang Pajak Penghasilan. Lembaran Negara RI Tahun 2008, No. 133. Sekretariat Negara. Jakarta 
(2007). Undang-Undang No. 28 Tahun 2007 tentang Perubahan Ketiga atas Undang-Undang nomor 6 tahun 1983 Tentang Ketentuan Umum dan Tata Cara Perpajakan. Lembaran Negara RI Tahun 2007, No. 85. Sekretariat Negara. Jakarta

. (2008). Undang-Undang Nomor 20 Tahun 2008 tentang Usaha Mikro, Kecil dan Menengah (UMKM). Lembaran Negara RI Tahun 2008, No. 93. Sekretariat Negara. Jakarta

. (1995). Undang-Undang Nomor 9 tahun 1995 tentang usaha kecil. Sekretariat Negara Jakarta. 